\title{
Growth and Yield Response of Signal Grass (Brachiaria decumbens Stapf) Applied with Different Rates of Nitrogen Fertilizer
}

\author{
Gina Arcuino Aguinod ${ }^{1}$, Nello Degracia Gorne ${ }^{*}$ \\ ${ }^{1}$ Department of Agronomy, Visayas State University, Visca, Baybay City, Leyte, Philippines, \\ orcid.org/0000-0003-4488-8390 \\ 2Department of Agronomy, Visayas State University, Visca, Baybay City, Leyte, Philippines, \\ orcid.org/0000-0003-3097-4191 \\ *Corresponding author: nello.gorne@vsu.edu.ph
}

Received: 27 June 2020, Accept: 04 November 2020, Published Online: 01 December 2020

\begin{abstract}
Application of fertilizers is essential to sustain the yield of forage crops, hence, this study was conducted to: 1) evaluate the effect of different nitrogen fertilization rates on the growth and yield of signal grass and 2) determine the appropriate nitrogen fertilization rate for optimum production of signal grass. It was laid out in a Randomized Complete Block Design (RCBD) with three replications and five treatments ( $T_{0}-$ Unfertilized, $T_{1}-30 \mathrm{~kg} \mathrm{~N}$ ha-1; $T_{2}$ $-60 \mathrm{~kg} \mathrm{~N} \mathrm{ha}^{-1} ; \mathrm{T}_{3}-90 \mathrm{~kg} \mathrm{~N} \mathrm{ha}^{-1}$ and $\mathrm{T}_{4}-120 \mathrm{~kg} \mathrm{~N} \mathrm{ha}^{-1}$ ). The plant height, number of tillers hill-1, fresh herbage yield and dry matter yield of signal grass were significantly affected by the different rates of nitrogen fertilizer. Increasing the levels of $\mathrm{N}$ fertilization correspondingly improved its overall performance with plants applied with $120 \mathrm{~kg} \mathrm{~N} \mathrm{ha}^{-1}$ having the tallest, most number of tillers and heaviest fresh herbage and dry matter yields among fertilized plants. However, the appropriate fertilization rate for optimum production was $90 \mathrm{~kg} \mathrm{~N} \mathrm{ha}^{-1}$ as the aforementioned parameters were comparable to that of the higher rate yet of lower amount of $\mathrm{N}$ fertilizer needed resulting in lower production cost and higher income.
\end{abstract}

Key words: Application, Dry matter, Herbage, Forage crop, Inorganic fertilizer

\section{Introduction}

Signal grass (Brachiaria decumbens Stapf) is a vigorous, rhizomatous and stoloniferous, medium-lived perennial grass (Heuzé et al., 2017). Although, it is a native of tropical Africa (Uganda), it has been introduced and distributed to other tropical countries (Fukumoto and Lee, 2003) being high yielding and adapted to a wide range of soils in the humid tropics (Heuze et al., 2017). It can be grazed or cut to be fed fresh or made into hay as 
it is palatable to all classes of livestock and withstands heavy grazing (Cook et al., 2005). It is also used as a cover crop to prevent erosion and to control weeds and insects (Mollot et al., 2012; Cook et al., 2005).

Forage production needs continuous replenishment of nutrients due to crop removal and other losses. Of all the essential plant nutrients, nitrogen $(\mathrm{N})$ is the most commonly deficient nutrient in soil and generally has the greatest impact on forage production. It is the nutrient most important in cell division and growth being the building block of proteins and a major component of chlorophyll. The effectiveness of $\mathrm{N}$ fertilizer on forage grasses is strongly influenced by rates, sources, times and methods of $\mathrm{N}$ application (Malhi et al., 2004). Timing of $\mathrm{N}$ fertilization depends on the $\mathrm{N}$ source and soil and climatic conditions which influence how quickly $\mathrm{N}$ becomes available from soil organic matter (Rutz and Jones, 2018).

In most situations, granular fertilizers are used for forage production. Urea is the dominant granular $\mathrm{N}$ fertilizer, as it has higher $\mathrm{N}$ content and is therefore less bulky and costs less per unit of $\mathrm{N}$ than other granular fertilizers. According to Malhi et al. (2004), urea and ammonium nitrate were equally efficient at increasing dry matter yield of hay type grasses but urea appeared to be a better source of $\mathrm{N}$ for pasture-type grasses.

Plants respond differently to $\mathrm{N}$ fertilization such that there is a need to investigate the response of signal grass to said fertilization. Moreover, addition of $\mathrm{N}$ fertilizer influences the chemical composition of the plant as well as the fertility status of soils. However, information on its fertilizer response is limited, hence, this study was conducted to evaluate the effect of different nitrogen fertilization rates on the growth and yield of signal grass and determine the appropriate nitrogen fertilization rate for its optimum production.

\section{Material and Methods}

Soil samples were randomly collected from the soil surface to a depth of $30 \mathrm{~cm}$ in the experimental area which were composited, mixed thoroughly, processed and a kilogram soil was submitted for laboratory analysis of soil $\mathrm{pH}$ (potentiometer method at 1:2.5 soil-water ratio), \% organic matter (Walkley-Black method), total $\mathrm{N}$ (Kjeldhal method) and extractable P (Bray No. 2). Right after the final harvest, soil sampling was done by collecting five samples from each treatment plot. The said samples were composited per treatment, mixed thoroughly, processed and analyzed for the same aforementioned soil parameters.

The experimental area was laid-out in a Randomized Complete Block Design (RCBD) replicated three times with five treatments ( $T_{0}-$ Unfertilized, $T_{1}-30 \mathrm{~kg} \mathrm{~N} \mathrm{ha}^{-1}, \mathrm{~T}_{2}-60 \mathrm{~kg} \mathrm{~N} \mathrm{ha}^{-1}, \mathrm{~T}_{3}-90 \mathrm{~kg} \mathrm{~N} \mathrm{~h}^{-1}$ and $\mathrm{T}_{4}-120$ $\mathrm{kg} \mathrm{N} \mathrm{ha}^{-1}$ ). Each treatment plot had a dimension of $3 \mathrm{~m} \times 3 \mathrm{~m}$ separated by $1 \mathrm{~m}$ alleyways.

Half of the required amount of nitrogen for each fertilized treatments together with the full amount of 30 $\mathrm{kg} \mathrm{P}_{2} \mathrm{O}_{5} \mathrm{~K}_{2} \mathrm{O}$ ha-1 $^{-1}$ were applied basally using urea (46-0-0), solophos (0-20-0) and muriate of potash (0-0-60), respectively. Right after the first harvest at 60 days after planting, the remaining amounts of nitrogen were applied.

The setts were planted $50 \mathrm{~cm} \times 50 \mathrm{~cm}$ apart on the ridges and appropriate cultural management practices were employed until harvesting. All the plants within the harvestable area were harvested at 60 and 105 days after planting by cutting the tillers $10 \mathrm{~cm}$ from the ground using a sharp sickle. 
The data gathered were plant height, number of tillers per hill, fresh herbage yield and dry matter yield as well as meteorological data such as weekly total rainfall and temperature that occurred during the conduct of the study.

\section{Results and Discussion}

\subsection{Agroclimatic conditions}

As presented in Table 1, the initial soil analysis revealed that the experimental area had a pH of 5.870 , $0.897 \%$ organic matter, $0.150 \%$ total nitrogen and $8.400 \mathrm{mg} \mathrm{kg}^{-1}$ available phosphorous. These results indicate that the soil was moderately acidic with very low organic matter and low total nitrogen and available phosphorus based on the soil chemical interpretation of Landon (1991).

Final soil analysis showed an increase in $\mathrm{pH}$ and a decrease in \% total nitrogen. On the other hand, \% organic matter increased only in plots applied with $30 \mathrm{~kg} \mathrm{ha}^{-1} \mathrm{~N}$ while available phosphorous increased in plots applied with $120 \mathrm{~kg} \mathrm{~N}^{-1}$ and $60 \mathrm{~kg} \mathrm{~N}^{-1}$. Such available phosphorous values were still lower than the 10.5 ppm considered by Suradej (2010) as extremely low for high yields of signal grass. However, Pastures Australia (2008) reported that signal grass tolerates low soil pH and adapted to soils of low fertility but is very responsive to applied $\mathrm{N}$ and $\mathrm{P}$.

Table 1. Soil $\mathrm{pH}$, organic matter, total $\mathrm{N}$ and available $\mathrm{P}$ of the experimental area before planting and after harvest of signal grass applied with different rates of nitrogen fertilizer.

\begin{tabular}{|l|c|c|c|c|}
\hline & Soil pH (1:2:5) & OM (\%) & Total N (\%) & Available P $\left(\mathrm{mg} \mathrm{kg}^{-1}\right)$ \\
\hline Initial Analysis & 5.870 & 0.897 & 0.150 & 8.400 \\
\hline Final Analysis & & & & \\
\hline $\mathrm{T}_{0}-$ Unfertilized & 6.660 & 0.819 & 0.127 & 8.127 \\
\hline $\mathrm{T}_{1}-30 \mathrm{~kg} \mathrm{~N} \mathrm{ha}^{-1}$ & 6.480 & 0.936 & 0.121 & 7.951 \\
\hline $\mathrm{T}_{2}-60 \mathrm{~kg} \mathrm{~N} \mathrm{ha}^{-1}$ & 6.370 & 0.858 & 0.115 & 10.225 \\
\hline $\mathrm{T}_{3}-90 \mathrm{~kg} \mathrm{~N} \mathrm{ha}^{-1}$ & 6.520 & 0.858 & 0.124 & 8.330 \\
\hline $\mathrm{T}_{4}-120 \mathrm{~kg} \mathrm{~N} \mathrm{ha}^{-1}$ & 6.410 & 0.897 & 0.122 & 9.011 \\
\hline Mean & 6.488 & 0.874 & 0.122 & 8.729 \\
\hline
\end{tabular}

The total weekly rainfall that occurred throughout the conduct of the study ranged from 0 to $567.40 \mathrm{~mm}$ (Figure 1). Such wide range of rainfall could probably be one of the consequences of climate change. Thus, supplemental application of water was done on weeks with limited moisture. The total amount of rainfall of 851.40 $\mathrm{mm}$ in 105 days growth period could have been adequate for the growth and development of signal grass if these were well distributed as best production of said grass in tropical coastal areas require rainfall $>1,500 \mathrm{~mm}^{-1}$ year-1 $^{-1}$ (Pastures Australia, 2008) or rainfall ranging from 1000 to $>3000 \mathrm{~mm}$ year-1 ${ }^{-1}$ Cook et al., 2005). 


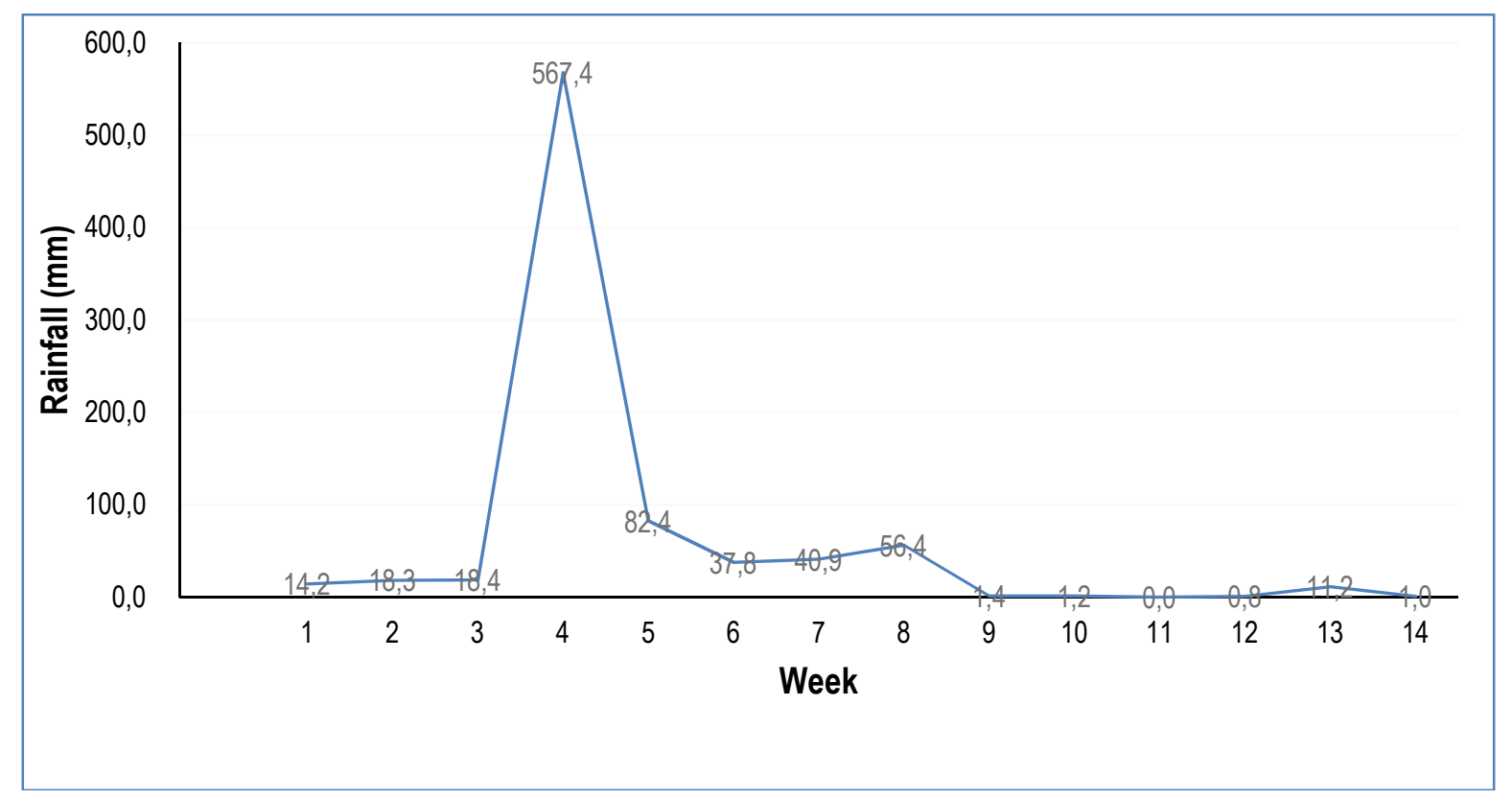

Figure 1. Rainfall $(\mathrm{mm})$ that occurred during the conduct of the study.

On the other hand, the average daily minimum and maximum temperatures ranged from 21.05 - 24.92 ${ }^{\circ} \mathrm{C}$ and $27.73-33.04{ }^{\circ} \mathrm{C}$, respectively (Figure 2). Said values closely conformed to the temperature requirements for optimal growth of signal grass which ranged from $30-35^{\circ} \mathrm{C}(\mathrm{FAO}, 2016)$.

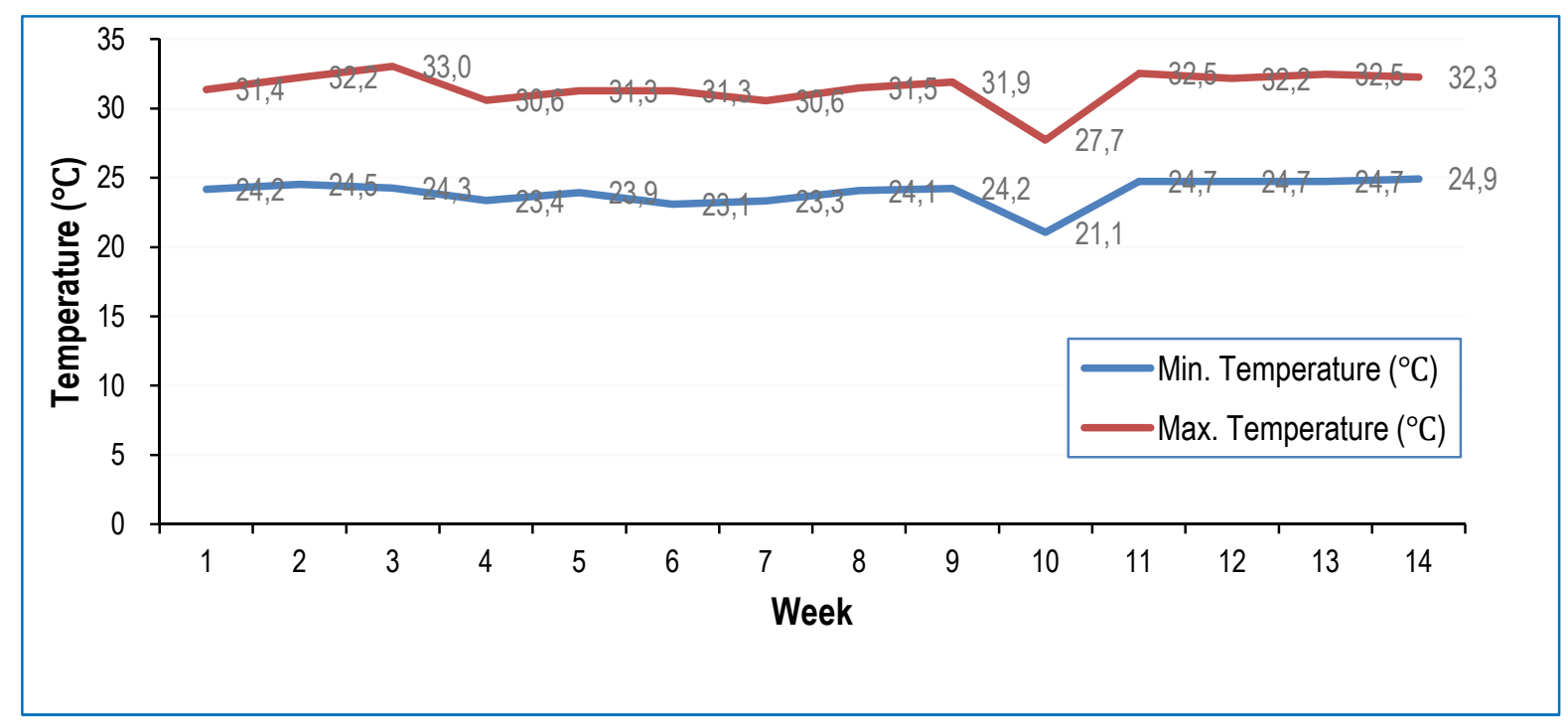

Figure 2. Minimum and maximum temperatures $\left({ }^{\circ} \mathrm{C}\right)$ that occurred during the conduct of the study.

\subsection{Agronomic characteristics}

Table 2 shows the agronomic characteristics of signal grass as affected by different levels of nitrogen fertilizer at first and second harvests. The plant height and number of tillers per hill were significantly influenced by nitrogen fertilization.

Plants applied with $120 \mathrm{~kg} \mathrm{~N}^{-1}$ were the tallest at $112.10 \mathrm{~cm}$ and $91.73 \mathrm{~cm}$ during the first and second harvests, respectively among fertilized plants except those plants applied with $90 \mathrm{~kg} \mathrm{~N}^{-1}$. The untreated plants 
were the shortest during the first harvest but were comparable to those plants applied with 30 and $60 \mathrm{~kg} \mathrm{~N} \mathrm{ha}^{-1}$ during the second harvest. Application of higher rates of nitrogen fertilizer significantly increased the overall growth performance of the plants since it is an essential component of DNA and protein, which are necessary for all plant processes. These findings confirmed the linear increase in plant height of signal grass with nitrogen fertilization reported by Souza et al. (2016).

The application of nitrogen fertilizer significantly increased the number of tillers per hill at first and second harvests. Higher number of tillers were observed on plants applied with 90 and $120 \mathrm{~kg} \mathrm{~N}^{-1}$ and fewer to those unfertilized plants. The results imply that as the rate of $\mathrm{N}$ fertilization increases, the number of tillers will likewise increase. These corroborated the results of Silva et al. (2013) who reported an increase in the number of vegetative tillers of marandu grass with $\mathrm{N}$ fertilization due to its positive effect on leaf elongation and tillering rate promoting greater capacity in the formation of axiliary buds, which may potentially originate new tillers. Likewise, Canto et al. (2020) reported significant increase in reproductive tiller density of signal grass at harvest for the first and second crops with $\mathrm{N}$ fertilization.

Table 2. Plant height $(\mathrm{cm})$ and number of tillers per hill of signal grass as influenced by different rates of nitrogen fertilizer at $1^{\text {st }}$ and $2^{\text {nd }}$ harvests.

\begin{tabular}{|c|c|c|c|c|}
\hline \multirow{2}{*}{ Treatment } & \multicolumn{2}{|c|}{ Plant height $(\mathrm{cm})$} & \multicolumn{2}{c|}{ No. of tillers per hill } \\
\cline { 2 - 5 } & 1st harvest $^{\text {nd }}$ harvest & $1^{\text {st }}$ harvest & $2^{\text {nd }}$ harvest \\
\hline $\mathrm{T}_{0}-$ Unfertilized & $82.18^{\mathrm{c}}$ & $65.20^{\mathrm{c}}$ & $19.60^{\mathrm{c}}$ & $48.43^{\mathrm{c}}$ \\
\hline $\mathrm{T}_{1}-30 \mathrm{~kg} \mathrm{~N} \mathrm{ha}^{-1}$ & $96.05^{\mathrm{b}}$ & $73.10^{\mathrm{bc}}$ & $37.60^{\mathrm{b}}$ & $80.73^{\mathrm{b}}$ \\
\hline $\mathrm{T}_{2}-60 \mathrm{~kg} \mathrm{~N} \mathrm{ha}^{-1}$ & $99.42^{\mathrm{b}}$ & $73.13^{\mathrm{bc}}$ & $40.27^{\mathrm{b}}$ & $80.57^{\mathrm{b}}$ \\
\hline $\mathrm{T}_{3}-90 \mathrm{~kg} \mathrm{~N} \mathrm{ha}^{-1}$ & $105.75^{\mathrm{ab}}$ & $85.23^{\mathrm{ab}}$ & $45.50^{\mathrm{ab}}$ & $99.97^{\mathrm{a}}$ \\
\hline $\mathrm{T}_{4}-120 \mathrm{~kg} \mathrm{~N} \mathrm{ha}^{-1}$ & $112.10^{\mathrm{a}}$ & $91.73^{\mathrm{a}}$ & $49.73^{\mathrm{a}}$ & $108.13^{\mathrm{a}}$ \\
\hline C.V. $(\%)$ & 6.67 & 12.01 & 12.75 & 11.40 \\
\hline
\end{tabular}

Treatment means within a column with the same letter are not significantly different at $5 \%$ level of significance based on Tukey's HSD test.

\subsection{Fresh herbage and dry matter yields}

Table 3 presents the effect of the different levels of nitrogen fertilizer on fresh herbage and dry matter yields of signal grass. Application of different rates of nitrogen significantly influenced the fresh herbage and dry matter yields of the plant.

Plants applied with 60,90 and $120 \mathrm{~kg} \mathrm{~N} \mathrm{ha}^{-1}$ had heavier total fresh herbage and total dry matter yields compared to the unfertilized plants and those plants applied with $30 \mathrm{~kg} \mathrm{~N} \mathrm{ha}^{-1}$. This is attributed to the increase in plant height and tiller number with increasing rates of nitrogen. According to Silva et al. (2013), tiller density increases with increasing nitrogen fertilization which linearly increases forage mass (Souza et al., 2016).

In terms of dry matter yield at first harvest, plants applied with $120 \mathrm{~kg} \mathrm{~N} \mathrm{ha}^{-1}$ had the heaviest dry matter yield than the rest of the plants applied with the other treatments. However, the plants applied with 60 and $90 \mathrm{~kg}$ $\mathrm{N}$ ha-1 ${ }^{-1}$ were of comparable yields to the former at second harvest and in terms of total yield. Lighter dry matter yields were obtained from the unfertilized plants and those applied with $30 \mathrm{~kg} \mathrm{~N} \mathrm{ha}^{-1}$. The result is in conformity 
with the reported increase in plant biomass of signal grass (Canto et al., 2020) and dry matter yield of palisade grass (Dupas et al., 2016) with $\mathrm{N}$ fertilization.

Table 3. Fresh herbage and dry matter yields of signal grass as influenced by different rates of nitrogen fertilizer.

\begin{tabular}{|l|c|c|c|c|c|c|}
\hline \multirow{2}{*}{ Treatment } & \multicolumn{3}{|c|}{ Fresh herbage yield $\left(\mathrm{t} \mathrm{ha}^{-1}\right)$} & \multicolumn{3}{c|}{ Dry matter yield $\left(\mathrm{t} \mathrm{ha} \mathrm{-}^{-1}\right)$} \\
\cline { 2 - 7 } & $1^{\text {st }}$ harvest & $2^{\text {nd }}$ harvest & Total & $1^{\text {st }}$ harvest & $2^{\text {nd }}$ harvest & Total \\
\hline $\mathrm{T}_{0}-$ Unfertilized & $2.66^{\mathrm{b}}$ & $6.38^{\mathrm{d}}$ & $9.04^{\mathrm{b}}$ & $0.75^{\mathrm{c}}$ & $1.13^{\mathrm{c}}$ & $1.88^{\mathrm{c}}$ \\
\hline $\mathrm{T}_{1}-30 \mathrm{~kg} \mathrm{~N} \mathrm{ha}^{-1}$ & $4.50^{\mathrm{b}}$ & $8.75^{\mathrm{c}}$ & $13.25^{\mathrm{b}}$ & $1.11^{\mathrm{c}}$ & $1.68^{\mathrm{bc}}$ & $2.79^{\mathrm{c}}$ \\
\hline $\mathrm{T}_{2}-60 \mathrm{~kg} \mathrm{~N} \mathrm{ha}^{-1}$ & $5.17^{\mathrm{ab}}$ & $9.88^{\mathrm{bc}}$ & $15.05^{\mathrm{ab}}$ & $1.88^{\mathrm{b}}$ & $2.32^{\mathrm{ab}}$ & $4.20^{\mathrm{ab}}$ \\
\hline $\mathrm{T}_{3}-90 \mathrm{~kg} \mathrm{~N} \mathrm{ha}^{-1}$ & $7.88^{\mathrm{a}}$ & $11.54^{\mathrm{ab}}$ & $19.42^{\mathrm{ab}}$ & $1.73^{\mathrm{b}}$ & $2.60^{\mathrm{a}}$ & $4.33^{\mathrm{ab}}$ \\
\hline $\mathrm{T}_{4}-120 \mathrm{~kg} \mathrm{~N} \mathrm{ha}^{-1}$ & $8.23^{\mathrm{a}}$ & $12.50^{\mathrm{a}}$ & $20.73^{\mathrm{a}}$ & $2.91^{\mathrm{a}}$ & $2.86^{\mathrm{a}}$ & $5.77^{\mathrm{a}}$ \\
\hline C.V. $(\%)$ & 29.84 & 9.99 & 19.92 & 19.66 & 17.42 & 18.54 \\
\hline
\end{tabular}

Treatment means within a column with the same letter are not significantly different at $5 \%$ level of significance based on Tukey's HSD test.

\subsection{Cost and return analysis}

As indicated in Table 4, the highest net income of $\mathrm{PhP5}, 804.44$ ha-1 $^{-1}$ was derived from signal grass

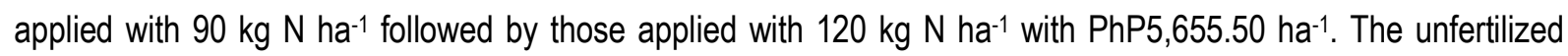
plants and those applied with $30 \mathrm{~kg} \mathrm{~N}^{-1} \mathrm{a}^{-1}$ incurred net loss of PhP1,680.00 ha-1 and PhP1,066.50 ha-1, respectively. The lesser income and net loss incurred was attributed to the low price of PhP1.75 per kilogram of herbage which did not offset the production cost incurred.

Table 4. Cost and return analysis of signal grass production as affected by different rates of nitrogen application.

\begin{tabular}{|l|c|c|c|c|}
\hline Treatments & $\begin{array}{c}\text { Total Fresh } \\
\text { Herbage Yield }\left(\mathrm{t} \mathrm{ha} \mathrm{-}^{-1}\right)\end{array}$ & $\begin{array}{c}\text { Gross Income }^{\mathrm{a}} \\
\left(\mathrm{PhP} \mathrm{ha}^{-1}\right)\end{array}$ & $\begin{array}{c}\text { Production Cost } \\
\left(\mathrm{PhP} \mathrm{ha}^{-1}\right)\end{array}$ & $\begin{array}{c}\text { Net Loss/Net Income } \\
\left(\mathrm{PhP} \mathrm{ha}{ }^{-1}\right)\end{array}$ \\
\hline $\mathrm{T}_{0}-$ Unfertilized & $9.04^{\mathrm{b}}$ & $15,820.00$ & $17,500.00$ & $-1,680.00$ \\
\hline $\mathrm{T}_{1}-30 \mathrm{~kg} \mathrm{~N} \mathrm{ha}^{-1}$ & $13.25^{\mathrm{b}}$ & $23,187.50$ & $24,254.00$ & $-1,066.50$ \\
\hline $\mathrm{T}_{2}-60 \mathrm{~kg} \mathrm{~N} \mathrm{ha}^{-1}$ & $15.05^{\mathrm{ab}}$ & $26,337.50$ & $26,221.20$ & 116.30 \\
\hline $\mathrm{T}_{3}-90 \mathrm{~kg} \mathrm{~N} \mathrm{ha}^{-1}$ & $19.42^{\mathrm{ab}}$ & $33,985.00$ & $28,180.56$ & $5,804.44$ \\
\hline $\mathrm{T}_{4}-120 \mathrm{~kg} \mathrm{~N} \mathrm{ha}^{-1}$ & $20.73^{\mathrm{a}}$ & $36,277.50$ & $30,622.00$ & $5,655.50$ \\
\hline
\end{tabular}

${ }^{a}$ Calculated by multiplying the fresh herbage yield with the price at PhP1.75 $\mathrm{kg}^{-1}$.

\section{Conclusion}

Application of nitrogen fertilizer significantly increased the plant height, number of tillers, fresh herbage and dry matter yields of signal grass. Except for the lowest $\mathrm{N}$ rate, the rest of the $\mathrm{N}$ fertilizer treatments significantly increased the aforesaid growth and yield parameters over the unfertilized treatment. Among these treatments, the appropriate rate of $\mathrm{N}$ application for optimum signal grass production was $90 \mathrm{~kg} \mathrm{~N}^{-1}{ }^{-1}$ for having a yield closer to that of $120 \mathrm{~kg} \mathrm{~N} \mathrm{ha}^{-1}$ but of lower production cost resulting in higher income.

\section{Conflicts of Interests}

Authors declare that there is no conflict of interests 


\section{References}

Canto, M. W., Pancera, E. J., Neto, A. B., Bremm, C., Vier, P. U., \& Costa, A. C. S. (2020). Effects of nitrogen fertilization and irrigation on seed yield and yield components of signal grass (Urochloa decumbens). Crop and Pasture Science, 71(3), 294-303.

Cook, B. G., Pengelly, B. C., Brown, S. D., Donnelly, J. L., Eagles, D. A., Franco, M. A., Hanson, J., Partridge, I. J., Peter, M., \& Schultze-Kraft, R. (2005). Tropical Forages: An interactive selection tool. Brisbane, Australia, CSIRO, DPI and F, CIAT, ILRI.

Dupas, E., Buzetti, S., Rabelo, F. H. S., Sarto, A. L., Cheng, N. C., Filho, M. C. M. T., Galindo, F. S., Dinalli, R. P., \& Gazola, R. N. (2016). Nitrogen recovery, use efficiency, dry matter yield, and chemical composition of palisade grass fertilized with nitrogen sources in the Cerrado biome. Australian Journal of Crop Science, 10(9), 1330-1338. https://doi:10.21475/ajcs.2016.10.09

FAO. (2016). Grassland Index. A searchable catalogue of grass and forage legumes. FAO, Rome, Italy.

Fukumoto, G. K., \& Lee, C. N. (2003). Signal Grass for Forage. Livestock Management (LM-3). Cooperative Extension Service, College of Tropical Agriculture and Human Resources. University of Hawail at Manoa.

Heuze, V., Tran, G., Boval, M., \& Lebas, F. (2017). Signal Grass (Brachiaria decumbens). Feedipedia, a programme by INRA, CIRAD, AFZ and FAO.

Landon, J. R. (1991). Booker Tropical Soil Manual: A Handbook for Soil Survey and Agricultural Land Evaluation in the Tropics and Subtropics. Longman Scientific and Technical, Essex, New York, 474.

Malhi, S. S., Gill, K. S., McCartney, D. H., \& Malmgren, R. (2004). Fertilizer management of forage crops in the Canadian Great Plains. Recent Research Developments in Crop Science, 1, 237-271.

Mollot, G., Tixier, P., Lescourret, F., Quilici, S., \& Duyck, P. F. (2012). New primary resource increases predation on a pest in a banana agroecosystem. Agricultural and Forest Entomology, 14(3), 317-325. https://doi:10.1111/j.1461-9563.2012.00571.x

Pastures Australia. (2008). Signal grass (fact sheet). Retrieved from https://keys.lucidcentral.org/keys/v3/pastures/Html/Signal_grass.htm

Rutz, K. O., \& Jones, C. (2018). Soil Nutrient Management For Forages: Nitrogen. Montana State University Extension, Bozeman, Montana.

Silva, D. R. G., Costa, K. A. P., Faquin, V., Oliveira, I. P., \& Bernardes, T. F. (2013). Rates and sources of nitrogen in the recovery of the structural and productive characteristics of marandu grass. Revista Ciencia Agronomica, 44(1), 184-191.

Souza, I. A., Ribeiro, K. G., Rocha, W. W., Carmo Araujo, S. A., Pereira, O. G., \& Cecon, P. R. (2016). Forage mass, chemical composition and leaf chlorophyll index of signal grass and organic matter in soil under increasing levels of Nitrogen. Semina: Ciencias Agrarias, Londrina, 37(3), 1505-1514. https://doi:10.5433/1679-0359.2016v37n3p1505 
Suradej, P. (2010). Soil nutrients and liming on dry weight yields and forage quality of signal grass (Brachiaria decumbens Stapf) grown on Korat soil series (Oxic Paleustults) in Northeast Thailand. Pakistan Journal of Biological Sciences, 13, 613-620. https://doi:10.3923/pjbs.2010.613.620 